\title{
Correction to: Future cloud: spherical processors for realizing low-cost upgrade in underwater data centers
}

\author{
A. A. Periola ${ }^{1}$ (D) O. A. Osanaiye ${ }^{2} \cdot$ A. T. Olusesi $^{1}$
}

Published online: 13 May 2021

๑) Springer Science+Business Media, LLC, part of Springer Nature 2021

\section{Correction to: The Journal of Supercomputing https://doi.org/10.1007/s11227-020-03571-w}

The original version of this article unfortunately contained a mistake in Eq. 24.

The correct version is given below:

$$
\mathrm{Vr}^{\mathrm{s}}=\left(\frac{C_{\text {demand }}-C_{r}^{S}}{\varphi}\right)^{-1} ; \quad r \in\{1,2\}
$$

The original article has been corrected.

Publisher's Note Springer Nature remains neutral with regard to jurisdictional claims in published maps and institutional affiliations.

The original article can be found online at https://doi.org/10.1007/s11227-020-03571-w.

\section{A. A. Periola}

periola@hotmail.com

O. A. Osanaiye

opeyemi.osanaiye@nileuniversity.edu.ng

A. T. Olusesi

ayobamiolusesi@yahoo.com

1 Department of Electrical, Electronics and Computer Engineering, Bells University of Technology, Ota, Nigeria

2 Department of Computer Engineering, Nile University of Nigeria, Abuja, Nigeria 